\title{
No Play No Gain: Is Exercise as Medicine Too Bitter a Pill to Swallow?
}

\author{
Darryl Edwards
}

Primal Play, darryl@primalplay.com

Despite the benefits of physical activity and exercise for health, recent research suggests that physical inactivity is endemic to our modern lifestyles. Most adults are risking their health by failing to get enough physical activity.

Is exercise as medicine too bitter a pill to swallow?

Even Muhammad Ali declared disdain for his exercise regimen,

"I hated every minute of training, but I said, 'Don't quit. Suffer now and live the rest of your life as a champion."' [1]

As far back as $2500 \mathrm{BC}$ in China, exercise for health promotion was documented [2]. In $600 \mathrm{BC}$, the surgeon Susrata, who lived nearly 150 years before Hippocrates, recommended moderate daily exercise and that physical activity should be used to treat obesity and diabetes [3]. Hippocrates promoted and prescribed exercise for physical health:

"That which is used develops, and that which is not used wastes away. If there is any deficiency in exercise, the body will become liable to disease, defective in growth and age quickly." [5]

He also spoke on the benefits for mental health too,

"If you are in a bad mood go for a walk. If you are still in a bad mood go for another walk!" [5].

If exercise came in pill form, we would only be too eager to take our keep-fit medicine. Even small doses extend longevity and prevent disease. [4]

Systematic research on this topic which began in the middle of the 20th century found increased heart disease risk with individuals in sedentary occupations than individuals in active occupations [6].

Recent studies tell us that exercise reduces all-cause mortality risk, [7] reduces cardiovascularrelated events [8], as well as warding off chronic lifestyle conditions such as type 2 diabetes [9], obesity $[10,11]$, metabolic syndrome $[12,13]$, dementia $[14,15]$, cancer $[16,17]$, chronic stress [18] and mental health disorders [19, 20].

Secondary prevention of coronary heart disease, stroke, heart failure, and prediabetes with physical activity is as effective as many drug interventions without the cost or side-effect burden of pharmaceuticals [21].

Measures to encourage physical activity as a strategy to tackle the emerging burden of chronic conditions such as the U.S. Surgeon General's call to action, as well as other Western government approaches to increase participation, are discouraging [22, 23].

WHAT ARE THE PHYSICAL ACTIVITY RECOMMENDATIONS? 
According to the World Health Organisation (WHO) and public health recommendations around the world adults aged 18-64 should do at least 150 minutes of moderate-intensity physical activity, or at least 75 minutes of vigorous-intensity physical activity weekly or a combination of the two [24].

There is a dose-response relationship, increasing to beyond 300 minutes a week of moderateintensity physical activity or 150 minutes a week of vigorous-intensity physical activity, and you will gain even more health benefits [25].

\section{MANKIND’S PATH TO A SEDENTARY LIFESTYLE}

We do not do enough when it comes to physical activity. Sedentarism is in stark contrast to our ancestral past. Our ancient ancestors chased prey as hunter-gatherers and avoided predation. They walked vast distances to gather, scavenge and forage for food. They had to be lean and fit in order to survive. For over 99 per cent of human prehistory, we lived as a species on the move [26,27,28].

More recently we were involved extensively with manual labour on farms and factories; we spent more time walking, did housework without the aid of labour-saving devices and spent no-time watching TV, playing computer video-games or browsing online [28].

Modern-day hunter-gatherers such as the Hadza spend vast amounts of their day in moderate-tovigorous-intensity activity and engage in 14 times as much movement in comparison to large epidemiological studies in the USA. The Hadza maintain this activity throughout their lifespan with low evidence of risk factors for cardiovascular disease and optimal levels for biomarkers of health [29].

\section{HOW MANY OF US MEET THE GUIDELINES?}

The percentage of US adults who regularly engage in the recommended amount of leisure-time exercise is estimated at approximately $30 \%$ [25]. Adherence to physical activity recommendations according to accelerometer-measured activity is significantly lower than self-reported data [30, 31, 32]. (see Table 1)

\section{Table 1.}

$\begin{array}{llc}\text { Category } & \text { Self-Reported } & \text { Accelerometer } \\ \text { UK Adult } & 35 \% & 5 \% \\ \text { US Adult } & 21 \% & 5 \% \\ \text { US Children } & 36 \% & 8 \% \\ \text { US Teen } & 25 \% & 8 \%\end{array}$

We do not have to go back that far to see evidence of a more active life, our grandparents were more active than our parents were, our parents were more active than we were and our children are likely to be less active than we are. We work more, with less labour. We have more leisure options, but less leisure time. We can perform more tasks but are less able to do so these tasks ourselves [28]. 


\section{MAYBE WORKOUTS ARE NOT WORKING OUT}

Even though gym memberships are becoming increasingly popular and offer increasingly diverse options, the attrition rate is high. According to research by the IHRSA (The International Health Racquet and Sportsclub Association) and FIA (The Fitness Industry Association) gyms lose up to $50 \%$ of their members annually $[33,34]$. Gyms supply a product that everyone wants, but that few people use. A study of nearly 8000 gym members found that members visited 4.5 times a month on average and paid $\$ 17$ more per visit than those who paid for a 10 -use pass at $\$ 10$ per visit [35].

A variety of factors that deter individuals from exercising include a lack of one or more of the following: motivation, time, energy, access to equipment, facilities, training partner, and selfefficacy $[35,36,37,38]$.

One overlooked factor is the association of exercise with significant discomfort - often we are targeted with marketing motivation such as "No Pain, No Gain!", "My warm-up is your workout!" and similar mantras, which have limited appeal.

\section{PLAYOUT RATHER THAN WORKOUT?}

Physical activity appears to be more regimented and less joyful in adults than in children, and recent research suggests that adults have lost their sense of play [40], especially concerning interactive social play [41]

We need to be reintroduced to the basic movement patterns that got us here [27] and instead of focusing on punishing workouts, we should focus on movement that will give us joy and pleasure. [28]

Movement connects us with the world in a variety of explorative and playful ways that are often overlooked and undervalued but essential for the mind, body and the brain. [42]

\section{CONCLUSION}

There is a universally low rate of regular exercise and physical activity participation, ignorance of the ongoing problem of exercise program adherence and a focus on exercise for aesthetics or health rather than joy.

Despite appearing frivolous, play is essential for healthy human development and could increase levels of physical activity participation. Not just for kids, but for adults too. [43]

Strategies should be developed to reframe fitness as fun based on playouts rather than workouts to engage otherwise inactive individuals.

Alternative approaches should be adopted to ensure that adults see joy and wellbeing as an essential part of their physical activity journey.

There may be a benefit in conducting randomised controlled trials examining play-based regimens vs conventional fitness programs to support improved mental and physical health, quality of life (QoL) markers and functional capability in greater depth. 


\section{References.}

[1] Vultaggio M. (2016 Apr). "Muhammad Ali Quotes On Training And Life: 20 Sayings Champion Said Before 2016 Death" [Web log post]. Retrieved October 31, 2018 from https:/www.ibtimes.com/muhammad-ali-quotes-training-life-20-sayings-champion-said-2016death-2377782

[2] Lee I M, Skerrett P J (2001). "Physical activity and all-cause mortality: what is the doseresponse relation?", Med Sci Sports Exerc., 2001 Jun; 33(6 Suppl):S459-71.

[3] Tipton C M (1985). "Susruta of India, an unrecognized contributor to the history of exercise physiology”, J Appl Physiol, 2008 Jun; 104(6):1553-6. doi:10.1152/japplphysiol.00925.2007.

[4] Hupin D, Roche F, Gremeaux V, Chatard J C, Oriol M, Gaspoz J M, Barthelemy J C, Edouard $\mathrm{P}$ (2015). "Even a low-dose of moderate-to-vigorous physical activity reduces mortality by $22 \%$ in adults aged $\geq 60$ years: a systematic review and meta-analysis", Br J Sports Med. 2015 Oct; 49(19):1262-7. http://dx.doi.org/10.1136/bjsports-2014-094306

[5] Grammaticos P C, Diamantis A (2008). "Useful known and unknown views of the father of modern medicine, Hippocrates and his teacher Democritus”, Hell J Nucl Med., 2008 Jan-Apr; 11(1):2-4.

[6] Morris J N, Crawford M D (1953). "Coronary heart disease and physical activity of work”, Br Med J, 1985 Dec; 2(5111): 1485-1496.

[7] Blair S (2009). "Physical inactivity: the biggest public health problem of the 21 st century", $\mathrm{Br}$ J Sports Med, 2009 Jan; 43(1):1-2.

[8] Nocon M, Hiemann T, Müller-Riemenschneider F, Thalau F, Roll S, Willich S N (2008). "Association of physical activity with all-cause and cardiovascular mortality: a systematic review and meta-analysis”, Eur J Cardiovasc Prev Rehabil, 2008 Jun; 15(3):239-46.

[9] Kyu H H, Bachman V F, Alexander L T, Mumford J E, Afshin A, Estep K, Veerman J L, Delwiche K, Iannarone M L, Moyer M L, Cercy K, Vos T, Murray C J L, Forouzanfar M H (2016). "Physical activity and risk of breast cancer, colon cancer, diabetes, ischemic heart disease, and ischemic stroke events: systematic review and dose-response meta-analysis for the Global Burden of Disease Study 2013”, BMJ, 2016 Aug; 354:i3857. https://doi.org/10.1136/bmj.i3857

[10] Shaw K A, Gennat H C, O'Rourke P, Del Mar C (2006). "Exercise for overweight or obesity", Cochrane Database of Systematic Reviews, Issue 4. Art. No.: CD003817.

[11] Collings P J, Westgate K, Väistö J, Wijndaele K, Atkin A J, Haapala E A, Lintu N, Laitinen T, Ekelund U, Brage S, Lakka T A (2016). "Cross-Sectional Associations of Objectively-Measured Physical Activity and Sedentary Time with Body Composition and Cardiorespiratory Fitness in Mid-Childhood: The PANIC Study", Sports Med. 2017 Apr; 47(4):769-780. https://doi.org/10.1007/s40279-016-0606-X 
[12] Carroll S, Dudfield M (2004). "What is the relationship between exercise and metabolic abnormalities? A review of the metabolic syndrome", Sports Med. 2004, 34(6):371-418. https://doi.org/10.2165/00007256-200434060-00004

[13] Ford E S, Kohl H W, Mokdad A H, Ajani U A (2005). "Sedentary behavior, physical activity, and the metabolic syndrome among U.S. adults", Obes Res. 2015 Mar; 13(3):608-14. https://doi.org/10.1038/oby.2005.65

[14] Ahlskog J E, Geda Y E, Graff-Radford N R, Petersen R C (2011). "Physical Exercise as a Preventive or Disease-Modifying Treatment of Dementia and Brain Aging", Mayo Clin Proc. 2011 Sep; 86(9): 876-884. https://dx.doi.org/10.4065\%2Fmcp.2011.0252

[15] Smith P J, Blumenthal J A, Hoffman B M, Cooper H, Strauman T A, Welsh-Bohmer K, Browndyke J N, Sherwood A (2010). "Review Aerobic exercise and neurocognitive performance: a meta-analytic review of randomized controlled trials", Psychosom Med. 2010 Apr; 72(3):23952. https://dx.doi.org/10.1097\%2FPSY.0b013e3181d14633

[16] Ekelund U, Ward H A, Norat T, Luan J, May A M, Weiderpass E, Sharp S J, Overvad K, Østergaard J N, Tjønneland A, Johnsen N F, Mesrine S, Fournier A, Fagherazzi G, Trichopoulou A, Lagiou P, Trichopoulos D, Li K, Kaaks R, Ferrari P, Licaj I, Jenab M, Bergmann M, Boeing H, Palli D, Sieri S, Panico S, Tumino R, Vineis P, Peeters P H, Monnikhof E, Bueno-de-Mesquita H B, Quirós J R, Agudo A, Sánchez M J, Huerta J M, Ardanaz E, Arriola L, Hedblad B, Wirfält E, Sund M, Johansson M, Key T J, Travis R C, Khaw K T, Brage S, Wareham N J, Riboli E (2015). "Activity and all-cause mortality across levels of overall and abdominal adiposity in European men and women: the European Prospective Investigation into Cancer and Nutrition Study", Am J Clin Nutr. 2015 Mar; 101(3):613-21. https://doi.org/10.3945/ajen.114.100065

[17] Moore S C, Lee I M, Weiderpass E, Campbell P T, Sampson J N, Kitahara C M, Keadle S K, Arem H, Berrington de Gonzalez A, Hartge P, Adami H O, Blair C K, Borch K B, Boyd E, Check D P, Fournier A, Freedman N D, Gunter M, Johannson M, Khaw K T, Linet M S, Orsini N, Park Y, Riboli E, Robien K, Schairer C, Sesso H, Spriggs M, Van Dusen R, Wolk A, Matthews C E, Patel A V (2016). "Association of leisure-time physical activity with risk of 26 types of cancer in 1.44 million adults", JAMA Intern Med. 2016 Jun; 176(6):816-25.

[18] Tsatsoulis A, Fountoulakis S (2006). "The protective role of exercise on stress system dysregulation and comorbidities". Ann N Y Acad Sci. 2006 Nov;1083:196-213. https://doi.org/10.1196/annals.1367.020

[19] Teychenne M, Costigan S A, Parker K (2015). "The association between sedentary behavior and risk of anxiety: a systematic review". BMC Public Health. 2015 Jun 19;15:513. https://doi.org/10.1186/s12889-015-1843-x

[20] Hopkins M E, Davis F C, Vantieghem M R, Whalen P J, Bucci D J (2012). "Differential effects of acute and regular physical exercise on cognition and affect". Neuroscience. $2012 \mathrm{Jul}$ 26;215:59-68. https://dx.doi.org/10.1016\%2Fj.neuroscience.2012.04.056 
[21] Naci H, Ioannidis J (2013). "Comparative effectiveness of exercise and drug interventions on mortality outcomes: metaepidemiological study". BMJ. 2013;347:5577 doi: https://doi.org/10.1136/bmj.f5577

[22] Department of Health (2011, Jul). "UK physical activity guidelines." Retrieved from https://www.gov.uk/government/publications/uk-physical-activity-guidelines.

[23] World Health Organisation, "Physical Activity Fact Sheet" (2018). Retrieved from https://www.who.int/dietphysicalactivity/factsheet_inactivity/en/.

[24] World Health Organisation (2018, Feb). "Physical Activity." Retrieved from http://www.who.int/news-room/fact-sheets/detail/physical-activity.

[25] Centers for Disease Control and Prevention (2016). "Physical Activity." Retrieved from http://www.cdc.gov/physicalactivity/data/facts.htm.

[26] Raichlen D A, Pontzer H, Harris J A, Mabulla A Z, Marlowe F W, Snodgrass J, Eick G, Berbesque C J, Sancilio A, Wood B M (2016). "Physical activity patterns and biomarkers of cardiovascular disease risk in hunter-gatherers", Am J Hum Biol. 2017 Mar;29(2). https://doi.org/10.1002/ajhb.22919

[27] Cordain, L, Gotshall, R, Eaton S B, Eaton SB $3^{\text {rd }}$ (1988). "Physical activity, energy expenditure and fitness: An evolutionary perspective", Int J Sports Med. 1998 Jul;19(5):328-35).

[28] Edwards, D (2013), "Paleo Fitness: Primal Training and Nutrition Program to Get Lean, Strong and Healthy", Ulysses Press, Berkeley.

[29] Raichlen D A, Pontzer H, Harris J A, Mabulla A Z P, Marlowe F W, Snodgrass J J, Eick G, Berbesque J C, Sancilio A, Wood B M (2016, Oct). "Physical activity patterns and biomarkers of cardiovascular disease risk in hunter-gatherers." American Journal of Human Biology: https://doi.org/10.1002/ajhb.22919

[30] British Heart Foundation (2008), "Physical Activity Patterns in Children", Retrieved from http://www.bhfactive.org.uk/userfiles/Documents/PApatternschildrenEngland.pdf

[31] Troiano R P, Berrigan D, Dodd K W, Mâsse L C, Tilert T, McDowell M (2008). "Physical activity in the United States measured by accelerometer", Med Sci Sports Exerc. 2008 Jan;40(1):181-8.

[32] Schoenborn C A, Adams P E (2010). "Health behaviors of adults: United States, 2005-2007”, Vital Health Stat 10. 2010 Mar;(245):1-132

[33] Dishman R K (1988). "Exercise adherence: Its impact on public health." Human Kinetics Books. Leeds.

[34] PTDirect (2017 Mar). Attendance, Adherence, Drop out and Retention. [Web log post]. Retrieved October 31, 2018 from http://www.ptdirect.com/training-design/exercise-behaviourand-adherence/attendance-adherence-drop-out-and-retention-patterns-of-gym-members 
[35] DellaVigna S, Malmendier U, (2006). "Paying Not to Go to the Gym", American Economic Review, 2006 Jun; 96 (3): 694-719. DOI: 10.1257/aer.96.3.694

[36] Chinn D J, White M, Harland J, Drinkwater C, Raybould S (1999). "Barriers to physical activity and socioeconomic position: Implications for health promotion" J Epidemiol Community Health. 1999 Mar; 53(3): 191-192.

[37] Ryan M R, Frederick C M, Lepes D, Rubio N, Sheldon K M (1997). "Intrinsic motivation and exercise adherence" Int J Sport Psychol. 1997; 28:335-354.

[38] Trost S, Owen N, Bauman A, Sallis A E, Brown W (2002). "Correlates of adults' participation in physical activity: Review and update", Med Sci Sports Exerc. 2002 Dec;34(12):1996-2001.

[39] Kahn E B, Ramsey L T, Brownson R C, Heath G W, Howze E H, Powell K E, Stone E J, Rajab M W, Corso P (2002). "The effectiveness of interventions to increase physical activity: A systematic review", Am J Prev Med. 2002 May;22(4 Suppl):73-107. doi: $10.1136 / \mathrm{bmj} .39320 .843947 . \mathrm{BE}$

[40] Thiel A, Thedinga H K, Thomas S L, Barkhoff H, Giel K E, Schweizer O, Thiel S, Zipfel S (2016). "An Observational Study of the Social Dynamics of Physical (in)activity in German and Hawaiian Leisure Settings", BMC Public Health. 2016; 16: 689. https://doi.org/10.1186/s12889016-3392-3

[41] Fassino, M. (1982). "Play: Structure and function. Behavioral and Brain Sciences", 5(1), 162163. https://doi.org/10.1017/S0140525X00011018

[42] Sheets-Johnstone, M. (1999). The Primacy of Movement. Amsterdam/Philadelphia: John Benjamins University Press (2nd ed. 2011).

[43] Blaisdell, Aaron P. (2015) "Play as the Foundation of Human Intelligence: The Illuminating Role of Human Brain Evolution and Development and Implications for Education and Child Development.," Journal of Evolution and Health: Vol. 1: Iss. 1, Article 9. http://dx.doi.org/10.15310/2334-3591.1016 